\title{
Populist Mobilization, Role of Political Elites and Anti-Centre Campaign in Recent Tamil Politics in India
}

\author{
Kunal Debnath \\ Assistant Professor \\ Department of Political Science \\ Kazi Nazrul University \\ Asansol 713340, West Bengal, INDIA \\ Email - debnathkunal@ymail.com; Mobile +919433673354
}

Kunal Debnath teaches political science in post graduate level at Kazi Nazrul University, India, since past three years. His research interest covers comparative politics, political sociology and political philosophy. Debnath is currently engaged with his doctoral research on the 'Nath Community' in India. Debnath published several research articles in several national and international peer-reviewed journals like Studies in Peoples History (Sage), Sexuality, Gender, and Policy (Policy Studies Organization, USA) on B.R. Ambedkar's ideas of nation-building in India, LGBT in India, etc. 


\title{
Populist Mobilization, Role of Political Elites and Anti-Centre Campaign in Recent Tamil Politics in India
}

\begin{abstract}
$\underline{\text { ABSTRACT }}$
Tamil politics in India has an enduring characteristic of a sub-nationalist orientation which, sometimes, bares with the populist mobilization by the political parties of Tamil Nadu. Recently, the working president of Dravida Munnetra Kazhagam, one of the prominent political parties of Tamil Nadu, recycles the issue of Dravida Nadu, a hypothetical land for the Tamils own based on their ethnonational identity, which had been dropped almost 55 years ago. Dravida Nadu highlights the linguistic, cultural and ethnonational resistance against north-Indian dominated pan-Indian nationalism. Cauvery water dispute, debate over Jallikattu, anti-Hindi stance, and protest against the terms of reference of the Fifteenth Finance Commission are the signs of anticentre campaign in Tamil politics and being used not only for upholding Tamil cultural nationalism but for mobilizing the people in electoral combat zone in Tamil Nadu.
\end{abstract}

Keywords: Dravida Nadu, ethnonationalism, secessionism, cultural nationalism, populist mobilization, anti-centre campaign. 


\section{Prologue:}

On March 16, 2018, after almost 55 years of dropping the demand of Dravida Nadu, a hypothetical land for the Tamils own, M.K. Stalin, leader and the working president of Dravida Munnetra Kazhagam (DMK), raised the issue of Dravida Nadu again. At a press conference in Erode, in response to a question asked by a journalist on the possibility of Dravida Nadu, Stalin says 'if it (such a situation) comes, it would be welcome. We hope that such a situation arises' (Kolappan, 2018). Though within a few hours Stalin clarifies his aforesaid statement as 'yes I had made remarks on Dravida Nadu but it was only after I was asked question on it but this does not mean that I am undertaking campaign for Dravida Nadu' (Asian News International, 2018). However, whether the statement of Stalin was campaign or not, the demand for Dravida Nadu is nothing new but it has a prolonged history. It took place during 1910 s by the Justice Party and reaccelerated during late 1940 s to 1960 s by the then DMK supremo C. N. Annadurai based on two principles - to protect Tamil interest and language, and second, Tamil Nadu was victimized by the North India dominated central government. But, after Sino-India war (1962), DMK gave up the demand for a separate state based on territorial nationalism in 1963. After 55 years of concentrating on their cultural nationalism, DMK calls for their territorial nationalism again. Stalin added, 'as far as Dravida Nadu is concerned, Anna (former Chief Minister C. N. Annadurai), gave up the idea, but also made it clear that the reasons for [the demand] for its creation are very much there. Anna has been proved right, especially now that we see how the southern states are being ignored by the BJP government' (The Hindu, 2018). Though it is not an extreme demand for separatism, but it hints at not only the fact that Centre has been trying to wrest states' power violating the federal structure of the State, but also shows a resistance from 
all the southern states against the saffronization of any institution, despite rest of the southern states (Karnataka, Andhra Pradesh, and Kerala) turned down the issue raised by M. K. Stalin.

\section{Trajectories of Dravidian Movement - from territorial to cultural nationalism:}

Historically, the Dravidian movement, one of the 'Asia's oldest and most durable ethnonational movements' (Subramanian, 1999, p. 15), was started on the basis of three separate issues and these issues were converged in a secessionist demand. The issues were: firstly, ethnocultural issues - Dravidian culture were followed by the majority of the people in erstwhile Madras Province and Brahmins were regarded as cultural invaders came from north India. Traditional Dravidian culture seemed to be more egalitarian than north Indian version of Hindu culture imposed upon the Dravidians by the Brahmins. It was primarily an anti-Brahmin nationalist movement. Secondly, language - more than $90 \%$ of the population spoke Dravidian family language (Tamil, Telugu, Kannada, and Malayalam) in the last decade of the British Raj. Dravidianism opposed politically dominant language Hindi. Entire south India was trembled by anti-Hindi agitation in 1965. Lastly, Religious impulse - early Dravidian movement had promoted atheism which supposed as the Dravidianist response to the humiliations imposed upon the lower castes by the Brahmanical Hinduism (Ziegfeld, 2003, p. 282). Based on this religious philosophy, early activists of the Dravidian movement publicly destroyed considerable amount of statues of Hindu deities and also organized self-respect marriage, 'wedding ceremonies conducted in Dravidianist families ritually validated by the speeches of political leaders rather than religious rituals performed by priests' (Subramanian, 1999, p. 108) with Sanskrit Mantras. However, this version of religious response never gained wide acceptance in Tamil Nadu (Ziegfeld, 2013, p. 283). 
The root of Dravidian politics dates back to pre-independence period when this part was known as Madras Presidency under the British Raj. Dravidian movement was initiated with a militant demand for secession and it opposed the Brahmin caste. First initiative was taken by the Justice Party, officially known as South Indian Liberal Federation, founded in 1916 by T. M. Nair, Theagaroya Chetty and C. Natesa Mudaliar and it was primarily elite non-Brahmin upper castes controlled political party. The Justice Party led Tamil movement opposed Brahmin supremacy in colonial Indian Civil Services. Another organization was also devoted to the Dravidian movement that was the Self-Respect Association founded in 1925 by E. V. Ramaswamy Naicker alias Periyar (aslo Periar). The Justice Party was primarily non-Brahmin elite based organization. For intensifying the movement, Periyar formed a mass based political party Dravidar Kazhagam (DK) in 1944. The DK was a merged form of Justice Party and SelfRespect Association. Journey of DK started from an elite based to mass oriented party with a new strategy of populist mobilization. Periyar identified Tamil Brahmins as cultural outsider came from northern part of India. For protecting the cultural purity as well as the interest of 'native' Dalits, Periyar called for the creation of a separate country in which the Dravidian-asSudra would enjoy prevalence. After independence of India, another party emerged in 1949 splitting DK by C. N. Annadurai, popularly known as 'Anna' or 'Elder Brother', who was much closed to Periyar in his early political career. C. N. Annadurai founded Dravida Munnetra Kazhagam (DMK), which portrayed itself as the defender of Tamil interest and language. Tamil Nadu was dubbed victimized By the DMK as having been culturally hegemonized by the central government having a task of promoting north Indian interests. Annadurai led DMK had a strong demand for Dravida Nadu which implies a territorial nationalist impulse of the Dravidian movement. Annadurai and his associates gave first a full version of nationalist dimension to the 
Dravidianism with a 'territorially rooted nation' while DK looked for the 'aggregate of megacastes' (Subramanian, 1999, p. 142). Transformation of the ideological differences between DK and DMK can be highlighted by the English translation of both the parties' name. Dravidar Kazhagam means 'Party of the Dravidians'. It highlights a group of people known as Dravidians. On the other hand, Dravida Munnetra Kazhagam means 'Party for the Progress of the Dravidam'. It refers to a land or country that is Dravidam. DMK was the first which specified the territorial boundary for a separate country supposed as Dravida Nadu, the place for Dravidians. For Annadurai, Dravida Nadu and Tamil Nadu were synonymous because all the Dravidians (south Indians) speak the language of Dravida language family. (Subramanian, 1999, p. 142). Then, 'Tamil Nadu [was] the first Indian state in which separatist/autonomist impulses developed despite initial enthusiasm about the creation of the Indian Union' (Subramanian, 1999, p. 131). But, since late 1960s and 1970s, all the potential issues for a secessionist movement in Tamil Nadu became non-issues through Indian typical model of federalism. Reasons laid on the rejection of a unitary state, the acceptance of multiple but complementary identities, the upholding of regional languages, maintenance of English as a 'link language', and the creation of mutually beneficial alliances between polity-wide and centric-regional parties (Stepan, 2010, pp. 350-370).

During 1960s, the DMK decided to drop its aspirations for territorial nationalism but never gave up their potentials for enjoying cultural nationalism. Reasons behind it were: after 1959 local government election in Madras city (now Chennai), DMK realized that they may be able to acquire state power and can demand for a greater autonomy; and a situation arose when separatist parties would have been declared illegal by the Constitution (Sixteenth Amendment) Act, 1963 made under the leadership of the then Prime Minister Jawaharlal Nehru, then separate 
statehood might be unworkable. Yet, the party constitution reflects a contradictory stance of DMK in response to greater integrity of south Indian states and adherence to the unity and integrity of India. Rule 2 of the party constitution ${ }^{1}$ says its aims as:

In conformity with the aims as laid down by Arignar Anna, the aim of the Kazhagam is to strive and forge Dravidian cultural co-operation among the four linguistic states of Tamil Nadu, Andhra Pradesh, Kerala and Karnataka, within the frame work of the sovereignty, unity and integrity of India and within the ambit of the Constitution of India. The Dravida Munnetra Kazhagam bears true faith and allegiance to the Constitution of India, as by law established and the principles of socialism, secularism and democracy and would uphold the sovereignty, unity and integrity of India.

1967 onwards, even after birth of the AIADMK (All India Anna Dravida Munnetra Kazhagam) ${ }^{2}$, formed in 1972 by M.G. Ramachandran (MGR), Tamil Nadu has been governing almost rotationally by the two major Dravidian parties without any extreme demand for separatism.

\section{Populism and Role of Political Elites:}

\footnotetext{
1 This party constitution of DMK has been adopted in 2003. Available at http://eci.nic.in/eci_main/misPolitical_Parties/Constitution_of_Political_Parties/Constitution_of_Dravida\%20Munnetra\%20Kazhagam.pdf
}

${ }^{2}$ Originally founded as Anna Dravida Munnetra Kazhagam (ADMK). The word 'Anna' referring to the lineage of the founder (C. N. Annadurai) of the parent party (DMK). MGR added 'All India' in 1977 to lay emphasis on 'the party's acceptance of pan-Indian nationalism'. Thus 'AIADMK' managed to attract the people who accepted the primacy of Tamil identity and pan-Indian nationalism simultaneously. For details, see Subramanian (1999: 264266). 
More or less, success of a political movement profoundly rests on the efficiency of the political elites who are able to successfully mobilize the masses using the popular issues, like ethnicity, culture and language, religion, caste, land, so on and so forth, intending to hold the political power. If end is pursuing the political power then mean is construction of a popular movement using popular issues in order to secure mass support. Dravidian movement can be seen by two distinct approaches - constructivist and instrumentalist. Demand of the Dravida Nadu is not the demand of the people state wide but an elite construction. Following A. D. Smith (1999, p. 30), Tamil people might be defined as an ethnie due to their myths of common lineage, 'shared historical memories and one or more elements of a common culture', common literature, common heroes, 'an association with a homeland', and most importantly, 'some degree of solidarity, at least among elites'. Therefore, Tamil community as a 'cohesive' and 'politicized' ethnie is an elite construction as it had been shaped politically, in its earlier phase, by the Justice Party and Self-Respect Association. Furthermore, Tamil identity is being used by the elites as an instrument to mobilize the masses to enjoy political dividend. Historically, all the parties associated at different times - the Justice Party, the Self-Respect Association, the DK, and the DMK - all of them put an attack on privilege, and to the shifts which took place from antiBrahmanism to Tamilism, from an identity based on race to language, and from territorial nationalism or secessionism to cultural nationalism (Harriss, 2001).

Dravidian parties have been bearing a strong and enduring features of populist mobilization. The DMK's ideological basis of populist mobilization was more 'assertive' than that of its predecessor DK's 'exclusive populism'. While DK's tactics of populist mobilization were fundamentally caste based, anti-Brahmanic and 'exclusionary' in nature, DMK focused principally on state or central governments pertaining to 'eclectric' Dravidian community than 
only opposing the Tamil Brahmins. Subramaniam examines this transformation as 'from a politics of heresy to a politics of community' (Subramanian, 1999, p. 312). Annadurai laid emphasis on 'all Tamil identity' by sloganeering 'Onre kulam, onruvane dhevan' (there is but one community/caste and one god). His 'all Tamil identity' was supposed to be an inclusive form of intermediate classes, such as backward classes, small property holders or plebeian class, and white collar workers. Contrarily, AIADMK's populist stance was more poor and downtrodden people centric and altruistic in nature. MGR's heroic presence in Tamil celluloid projected him as he can be protective in reality likewise he appeared in Tamil celluloid as a protector of the interests of the poor people and women. This is an instance of 'routinization of charisma' to form an authority based on state's legal institutions. Thus, subsidy in basic commodities and agriculture, supplying food and liquor, preferential quota, etc. policies were in centre of MGR led AIADMK's 'paternalist populism' unlike DMK's stance of ethnic militancy (Subramanian, 1999). Subramanian (1999, p. 246) takes a few lines from one of MGR's film songs to demonstrate his paternalist populist stand: 'Naan aanaittaal, adhu nadanthuvittaal, Intha yezhaigal vedhanai padamaattaar' (If I were to command, if my wish became true, these poor people will no longer suffer).

But this kind of populist strategy might be miscarried 'to unite the majority of people against a common enemy by addressing them as a single category [because] some newly mobilized groups [may label] themselves as relatively more disprivileged' (Harriss, 2001). And it happened to the Dravidian parties, especially to the DMK. As in another writing John Harriss speaks of "the renewal of caste conflict in the state, it is rather hard to accept the notion that Dravidian populism has been such a great "success" because, as he further writes, 'it is widely felt the rule of Dravidian parties has become increasingly authoritarian, and focused on "the 
leader" - at the centre' (Harriss, 2003, p. 105). M.S.S. Pandian also claims that uneven development and caste arrogance among non-Brahmin elite castes in Tamil society led to rise serious tensions in Tamil Nadu (Pandian, 1994). So, it is indeed a great challenge to DMK to wipe out the caste cleavages and regain its support base what it lost.

\section{Anti-Centre Leanings in Recent Tamil Politics:}

An indispensable question might come at this point that what happened in recent times that Mr. Stalin lays emphasis particularly on the issue of Dravida Nadu! The probable answer lies on the centre-state relations under the federal framework of Indian Union particularly in the Bharatiya Janata Party (BJP) commanded National Democratic Alliance (NDA) - II regime, and second, the distinctive characteristic of the politics of Dravidianism. Indian quasi federal structure made more powerful centre vis-à-vis powerless states. In India, states are created, organized and reorganized by the Centre. Constitutional arrangements in India made high blood pressure in Centre and anaemia in periphery or states. Tamil Nadu has a fertile land to breed anticentre campaign on various issues over the decades in response to the tendency of overcentralizing the power in New Delhi. Here, in recent times four issues are noteworthy while discussing anti-centre campaigning in Tamil Nadu. Firstly, Cauvery water issue is a longstanding bilateral (even multilateral since Kerala and Puducherry both are also associated) disputation started during 1890s between erstwhile Madras Province and Princely State Mysore. After two phases of legal settlement in 1892 and 1924 it was solved temporarily. The 1924 agreement was planned for 50 years and supposed to be reviewed in 1974, but not continued because Karnataka felt discriminated and no longer sought to continue the agreement. This issue is an apposite example of an inter-state and also a centre-state conflict. According to article 262 of the Indian constitution, Parliament is empowered to provide law for the adjudication of disputes relating to 
waters of inter-state rivers or river valleys. Under this provision the Parliament has enacted the Inter-State Water Dispute Act (1956), and this act empowers the Central government to set up tribunal for the adjudication of disputes relating to waters of inter-state rivers or river valleys. Despite several requests made by Tamil Nadu Government, after many procrastinations, the Central government finally constituted the Cauvery Water Dispute Tribunal (CWDT) in 1990. But, as CWDT is cited here, neither the interim award in 1991 nor the final award in 2007 of CWDT could satisfy both the states. Tamil Nadu claims that the water released from Karnataka reservoirs is not like a gift but a legitimate right of the farmers of Tamil Nadu (Janakarajan, 2016). On the other side, Karnataka is reluctant to implement the final award of CWDT and even Supreme Court's settlement made on February 16, 2018. Meanwhile, Kamal Hasan and Rajinikanth, two film stars, questioned on the ethical ground of conducting Indian Premier League (IPL) matches in Chennai when Tamil Nadu is undergoing an acute water crisis and thus agrarian crisis. Tamil Nadu's situation is much more severe because 'over one-third of its population lives in the Cauvery basin and depends upon the river Cauvery for virtually all its needs' (Janakarajan, 2016). Tamil people extended their campaign not only against the Karnataka government, but also against the Supreme Court along with the Centre because either of them failed to ensure the legitimate right to use water of the river Cauvery.

As touched upon earlier, language is crucial to be taken as a serious issue in Tamil politics. Tamil Nadu has witnessed a DMK-led anti-Hindi agitation in 1965 which foiled the plan of the Lal Bahadur Shastri government to adopt Hindi as sole official language in India. On March 31, 2017, the then President of India Sri Pranab Mukherjee in principle accepted some recommendations of the 'Committee of Parliament on Official Languages' submitted in 2011. In serial number 105, it recommends 'all dignitaries including Hon'ble President and all the 
Ministers especially who can read and speak Hindi may be requested to give their speech/statement in Hindi only'. Another recommendation was in serial number 111 as purchase of Hindi newspapers and magazines should be made mandatory in all central government offices and number of Hindi newspapers and magazines should be more than that of English newspapers and magazines. It proposes also to make Hindi a compulsory subject from class eight to class ten in all Kendriya Vidyalaya (Central School) and all the schools affiliated to Central Board of Secondary Education (CBSE). Moreover, Air India, state owned airline, has been asked to use Hindi while issuing tickets. In response to the central government's manoeuvre to promote Hindi as a part of BJP's slogan 'Hindi, Hindu, Hindusthan', on April 22, 2017, Stalin warns the central government not to invite another anti-Hindi agitation by the policy of Hindi imposition over the non-Hindi speakers. Putting emphasis on English instead of Hindi as a link language among the diversified linguistic groups in India, former Tamil Nadu Chief Minister C. N. Annadurai's said in Parliament in 1963:

I speak English not because I am enamoured by it, but because it is a convenient tool, it is the most convenient medium which distributes advantages or disadvantages evenly. If the British were to remain here and say, take it (English), then we will have to resist it. But now there is no question of imposition of English by the British... the consequence of the imposition of Hindi as the official language will create a definite, permanent and sickening advantage to the Hindi-speaking States (Aiyar, 2014).

The BJP led central government, however, says that the Committee of Parliament on Official Languages has been working since its constitution in 1976 and submitted its recommendation in 2011. Central government also clarifies the recommendation on speak in Hindi by the President 
and Ministers as it is only recommendatory and not mandatory; it is in the form of a request and does not entail any form of Order/Instruction. But it goes without saying that these clarifications are not adequate to pacify the disquiet not only in Tamil Nadu, but in other non-Hindi speaking states.

Another issue is Jallikattu, a cultural event with bulls takes place during a harvest festival of Pongal. Jallikattu, derived from two words Jalli (coins) and Kattu (tied), literally means 'grabbing a bag of coins tied to the horns of the bulls' (Kalaiyarasan, 2017), attracted the world's attention after being banned by the Supreme Court of India in 2014 preceded by a petition made under the banner of Animal Welfare board of India (AWBI) and People for the Ethical Treatment of Animals (PETA). It was banned allegedly that 'the sport is not about bull taming but embracing them' (Kalaiyarasan, 2017). On the other hand, for the supporters of Jallikattu, it became 'a symbol of pride' since this ban can be seen as an attack on Tamil culture and identity. Jallikattu issue became important in 2017 because it triggered another issue - anti-centre strand of Tamil masses. So, as 'the anti-Hindi agitation was not simply about the language, [likewise] Jallikattu protest was not just about a sport' (Kalaiyarasan, 2017) rather it has a greater implication to shape the recent Tamil politics. Jallikattu protest upturns another question relating to the Cauvery water issue. The slogans and placards in Jallikattu protest probed 'why Tamil Nadu should respect the Supreme Court when it cannot enforce the water rights of Tamil Nadu' (Kalaiyarasan, 2017).

Economic issue is also central to anti-centre campaign by M. K. Stalin. Stalin raised an issue of Centre's fund allocation to the states by the recommendation of the Fifteenth Finance Commission (XVFC). He says it as 'travesty of justice' attacking the 'Terms of Reference' (ToR) of XVFC. As per ToR of XVFC, 2011 population census would be entertained instead of 
1971 population census as a basis while making its recommendations for the devolution of taxes from the Central government to the states. The $42^{\text {nd }}$ Constitutional Amendment (1976) held the 1971 census as the basis for all calculations till the 2001 census. Subsequently, the $84^{\text {th }}$ Amendment (2001) further extends it to the first census after 2026, which will be the census 2031. Stalin highlights the anxiety of Tamil Nadu because while states like Uttar Pradesh, Maharashtra and Bihar have more than doubled their population in the intervening years, southern states like Tamil Nadu, Karnataka and Kerala have relatively slower growths. Only Andhra Pradesh went almost more than double. Leaders from the southern states point out the discrepancy that the more who have worked well on population control, the more they will lose out on benefits. On the other hand, comparatively, northern states have lagged to control population, but they will get more financial benefits. Nilakantan R.S. (2018) indicates the poor budgetary expenditure of the southern states vis-à-vis their opulent contributions to the national GDP. For example, while Tamil Nadu's GSDP is 15.9 lakh crore, Uttar Pradesh's is 14.8 lakh crore, but total budget expenditure of Tamil Nadu is 1.1 lakh crore while Uttar Pradesh has 1.5 lakh crore for 2018-19. That is, 'if these two states were independent entities, Tamil Nadu's economic output would be higher than that of Uttar Pradesh's notwithstanding the latter being three times more populous than the former' [but] 'Uttar Pradesh has a budget outlay that's 36\% higher than Tamil Nadu despite having an economy that's 7\% smaller' (Nilakantan, 2018). This is true for other southern states like Kerala, Karnataka and Andhra Pradesh have smaller budgets than what their economies would otherwise warrant. Telugu film actor cum politician Pawan Kalyan, Siddaramiah, Karnataka's Chief Minister, also spoke against this population based formula for sharing tax revenues among the states. Stalin writes to the Chief Ministers of ten 
states perhaps 'not coincidentally' governed by non-BJP parties seeking their support to make a demand on reframe the ToR.

\section{Epilogue:}

M. K. Stalin recycles Dravida Nadu with several specific reasons. The DMK is now in opposition in Tamil Nadu government from last eight years and hunting for an issue to remobilize the people in favour of them. Notwithstanding gigantic scams cast a shadow in Jayalalithaa's political career as well as her personal image but the paternalist (better to say maternal in this case particularly) populist stance such as welfare schemes to the poor people made 'her transformation from Golden Lady of the 1980s to the revolutionary leader of 1990s, to her final avatar as “Amma” (Mother)' to the common people (Karthikeyan, 2018). After demise of Jayalalithaa, popular sympathy is with AIADMK despite AIADMK is undergoing some internal crises like civil war ${ }^{3}$ and corruption. The DMK also wants to regain its support base after heaved a sigh of relief receiving clean cheat by virtue of the verdict given by the Special CBI Court on December 21, 2017 in 2G spectrum scam where members of DMK, including M. Karunanidhi's daughter as well as DMK Member of Parliament M. K. Kanimozhi, were accused allegedly they were involved in the scam. On the other hand the DMK does not have a wellorganized successor after M. Karunanidhi, popularly known as Kalaignar to his supporters.

\footnotetext{
${ }^{3}$ After demise of 'Amma' Jayalalithaa in December 2016, AIADMK undergone a serious inner conflict between Amma's friend V. K. Sasikala and O. Panneerselvam, a trustworthy of Amma. AIADMK had been divided as AIADMK (Puratchi Thalaivi Amma) under Panneerselvam's leadership and AIADMK (Amma) under the leadership of Palaniswami who was appointed the Chief Minister by Sasikala. Dhinakaran, nephew of Sasikala, was appointed the Deputy General Secretary of AIADMK. After two factions merged on August 21, 2017, Palaniswami remains as Chief Minister and Panneerselvam became Deputy Chief Minister. Dhinakaran launched a political party Amma Makkal Munetra Kazhagam on March 15, 2018.
} 
While speaking or campaigning, Stalin has always been using his father as a trump card. He is popular only in Chennai but in other parts of Tamil Nadu people do not prefer Stalin as a mass leader unlike how they preferred Kalaignar over the years. They consider Stalin only as a city Mayor or Minister because of his poor political knowledge in other than Chennai regions.

Another possible reason might be the emergence of two celluloid heroes in recent Tamil politics. Kamal Hasan and Rajinikanth, the two well-known film protagonists, both have come into the Tamil as well as country's political scene. Kamal Hasan, a self-acclaimed admirer of Periyar, formed a party named 'Makkal Needhi Maiam' (People's Centre for Justice). Kamal Hasan's political lane is subsumed under secularism. On the other hand, Rajinikanth desires to form a political party based on spirituality. The two celluloid personalities' paths are different but the destination is same - weed out corruption from the system, and the welfare of the common people. Ends are same but the means are different. Both Hasan and Rajinikanth claim that the rule of Dravidian parties should end in the state primarily because of rampant corruption promoted by their populist measures (Krishnan, 2018). As, epistemologically, Dravidian movement is based on caste inequality between non-Aryan, non-brahmin Dravida people and Aryan Brahmin people, then caste identity and religious impulse are very much embedded in Dravidian politics. Though, Kamal Hasan defines Dravidian identity as based on geography to mobilize people beyond the caste identity. Rajinikanth clarifies his politics above religion and caste despite he embraces spiritual basis of politics primarily rejecting secularism (Krishnan, 2018).

So, DMK is supposed to compete with this new kind of political vigour in its upcoming future. DMK's demand of Dravida Nadu needs to be seen from this angle too. The demand for Dravida Nadu is like 'make hay while the sun shines' and a political trick in order to mobilize 
the Tamils in favour of DMK. Though the Dravidian movement pivoted on the secessionist demand, but it is also worth considering that secession never became an extreme mass sentiment in south India. But, sometimes, the Dravidian parties use this 'language of secession' for mobilizing people in favour of them in electoral combat zone even after officially giving up the demand of separate statehood (Stepan, 2010, pp. 348-349). In a nutshell, Dravida Nadu highlights the antagonism between unjust distribution of economic resources by the central government and resistance of Tamil Nadu along with south Indian states. It is also indicative to the resistance against the endeavour of cultural and linguistic domination of north India over south India. It indicates a confrontation between pan-Indian nationalism and south-Indian subnationalism. Finally, it is a political ploy of DMK for mobilizing the people and rebuild a support base to grasp the political power.

\section{Declaration of Conflicting Interests:}

The author(s) declared no potential conflicts of interest with respect to the research, authorship, and/or publication of this article.

\section{Funding:}

The author(s) received no financial support for the research, authorship, and/or publication of this article.

\section{References:}

Aiyar, M. S. (2014, June 28). Mani-Talk: 'No English. No Hindi. How?'. Retrieved May 25, 2018, from NDTV: https://www.ndtv.com/opinion/mani-talk-no-english-no-hindi-how582020 
Asian News International. (2018, March 17). Retrieved April 22, 2018, from https://twitter.com/ANI/status/974925667669368833/photo/1

Harriss, J. (2001). Populism, Tamil Style. Is It Really A Success? Working Paper series, Development Studies Institute, London School of Economics and Politics(01-15).

Harriss, J. (2003). Whatever Happened to Cultural Nationalism in Tamil Nadu? A Reading of Current Events and the Recent Literature on Tamil Politics. In A. Wyatt, \& J. Zavos (Eds.), Decentring the Indian Nation (pp. 93-112). London: Frank Cass.

Janakarajan, S. (2016, October 8). The Cauvery Water Dispute: Need for a Rethink. Economic \& Political Weekly, LI(41), 10-15.

Kalaiyarasan, A. (2017, February 11). Politics of jallikattu. Economic \& Political weekly, LII(6), $10-13$.

Karthikeyan, D. (2018, January 13). A Colossus of Tamil Politics: Jayalalithaa's Journey. Economic \& Political Weekly, LIII(2), 27-29.

Kolappan, B. (2018, March 17). Stalin for 'Dravida Nadu'. Retrieved April 22, 2018, from The Hindu: http://www.thehindu.com/news/national/tamil-nadu/stalin-for-dravidanadu/article23275669.ece

Krishnan, R. K. (2018, April 21). Tamil Politics without Caste? Economic \& Political Weekly, LIII(16), 20-22.

Nilakantan, R. S. (2018, March 20). The Economics and Politics Behind Dravida Nadu or South Indian Subnationalism. Retrieved April 4, 2018, from The Wire: https://thewire.in/economy/economics-politics-behind-dravida-nadu-or-south-indiansubnationalism 
Pandian, M. S. (1994, January 29). Crisis in DMK. Economic and Political Weekly, 29(5), 221223.

Smith, A. D. (1999). Myths and Memories of the Nation. Oxford: Oxford University Press.

Stepan, A. (2010). Federalism, Multinational Societies, and Negotiating a Democratic 'State Nation': A Theoretical Framework, the Indian Model, and a Tamil Case Study. In S. Barua (Ed.), Ethnonationalism in India : A Reader (pp. 347-378). New Delhi: Oxford University Press.

Subramanian, N. (1999). Ethnicity and Populist Mobilization: Political Parties, Citizens and Democracy in South India. New Delhi: Oxford University Press.

The Hindu. (2018, March 17). Calls for Dravida Nadu stem from neglect of States: Stalin. Retrieved April 22, 2018, from http://www.thehindu.com/news/national/tamil-nadu/callsfor-dravida-nadu-stem-from-neglect-of-states-stalin/article23282944.ece

Ziegfeld, A. (2013). Tamil Nadu. In A. Kohli, \& P. Singh (Eds.), Routledge Handbook of Indian Politics (pp. 283-290). Oxon: Routledge. 